\title{
Growth in Area, Production and Productivity of Food Grains in Karnataka State, India
}

\author{
N.L. Pavithra ${ }^{*}$, K.V. Ashalatha, J. Megha, G.R. Manjunath and Siddu Hanabar \\ Department of Agricultural Statistics, College of Agriculture, UAS, Dharwad-580005, \\ Karnataka, India \\ *Corresponding author
}

\section{A B S T R A C T}

\begin{tabular}{|l|}
\hline Ke y w or d s \\
Compound annual \\
growth rate, \\
Significant, Area, \\
Production, \\
Productivity etc. \\
\hline Article Info \\
\hline $\begin{array}{l}\text { Accepted: } \\
15 \text { July } 2018 \\
\text { Available Online: } \\
\text { 10 August } 2018\end{array}$ \\
\hline
\end{tabular}

Karnataka state has a typical composition having a large share of its area under highly diversified agricultural crops, higher growth in agriculture assumes great importance and is a matter of concern for policy planners and research scholars in recent times. The analysis of growth is usually used to find out the trend of a particular variable over a period of time and used for making policy decisions. The growth in the area, production and productivity of food grains in Karnataka was estimated using the compound annual growth rate analysis. The necessary secondary data were collected for a period of 25 years from 199091 to 2014-15. Growth rates showed a significant positive growth in case of both cereals and pulses. In case of cereals, the highest positive CAGR was observed in maize area and production. Paddy and sorghum were found to be non-significant for growth of area, production and productivity. Among the pulses, chickpea and pigeonpea exhibited a significant positive growth rate in case of area, production and productivity. Field bean showed significant positive growth in case of production and productivity. Horse gram, black gram and green gram were found to be non-significant.

\section{Introduction}

Agricultural growth is necessary not only for attaining high overall growth but also for accelerating the poverty reduction in a developing country like India.

The annual compound growth rates of the agricultural sector have been quite robust ranging from 2 per cent to 3 per cent after independence. However, the non-agricultural sector has grown faster than the agricultural sector and the divergence between agricultural growth and overall economic growth has widened over time, particularly since 1980s. The India's total GDP growth accelerated from 3.3 per cent per annum in the 1980s to 6.0 per cent in the $1990 \mathrm{~s}$, and further to 7.8 per cent during the 2000s. The critics of the Indian agricultural development strategies argue that the growth in agriculture is regionally concentrated, and is confined to a few commodities.

The disaggregated analysis of agricultural productivity would decipher these issues and will help in identifying and prioritizing the districts for agricultural development. 
Karnataka State has a typical composition of having a large share of its area under severe climatic constraints with a highly diversified agricultural sector. The main crops grown here are paddy, ragi, jowar, maize and pulses, besides oilseeds and number of cash crops viz., cashews, coconut, arecanut, cardamom, chillies, cotton, sugarcane and tobacco (Ramachandra et al., 2013). Karnataka is the largest producer of coarse cereals, coffee, raw silk and tomatoes among the states in India. Under these circumstances, growth in agriculture assumes greater importance and is a matter of concern for policy planners and research scholars in recent time frame. In view of this, the present study aimed to analyse the growth in area, production and productivity of food grains in the state.

\section{Materials and Methods}

The study on growth in area, production and productivity of food grains was purposively taken up in Karnataka state of India. The secondary data on area, production and productivity of food grains were used to analyze the trends. The time series data on area, production and productivity of food grains was available from 1991 onwards. Hence the analysis was covered for the period from 1990-91 to 2014-15. Data used for the study was collected from various published source i.e., Directorate of Economics and Statistics (DES), Bangalore, Karnataka.

The growth in the area, production and productivity under food grains was estimated using the compound annual growth rate analysis.

\section{Compound annual growth rate analysis}

For computing compound growth rate of area, production and productivity of selected food grains, the exponential function of the following form was used.
$\mathrm{Y}=\mathrm{a} \mathrm{b}^{\mathrm{t}} \mathrm{e}^{\mathrm{U}}{ }_{\mathrm{t}}(1)$

Where,

$\mathrm{Y}=$ Area /productivity/production

$\mathrm{a}=$ Intercept

$\mathrm{b}=$ Regression coefficient

' $a$ ' and ' $b$ ' are the parameters to be estimated

$\mathrm{t}=$ time period

$\mathrm{U}_{\mathrm{t}}=$ Disturbance term in year ' $\mathrm{t}$ '

The equation (1) was transformed into log linear form and written as;

$\log \mathrm{Y}=\log \mathrm{a}+\mathrm{t} \log \mathrm{b}+\mathrm{U}_{\mathrm{t}}(2)$

Equation (2) was estimated by using Ordinary Least Squares (OLS) technique.

Compound growth rate (g) was then computed

$g=(b-1) 100(3)$

Where,

g: Compound growth rate in per cent per annum

b: Antilog of $\log b$

The standard error of the growth rate was estimated and tested for its significance with ' $t$ ' statistic.

\section{Results and Discussion}

The results of compound growth rate analysis for the food grains in Karnataka state from 1990-91 to 2014-15 is furnished in Table 1. The highest positive growth observed in maize area and production were 7.74 per cent and 7.64 per cent, respectively. Negative growth was observed in maize productivity i.e., -0.10 per cent. The negative significant growth was observed in area of finger millet i.e., -1.81 per cent in the study. Though pearl millet showed 
non-significant growth in case of area and production it showed significant positive growth in productivity. Among cereals, paddy and sorghum were found to be non-significant for growth of area, production and productivity. Among the pulses, chickpea exhibited a significant positive growth rate in case of area, production and productivity i.e., 6.68 per cent, 8.96 per cent and 2.14 per cent, respectively. Field bean showed significant positive growth in case of production 7.28 per cent and productivity 8.30 per cent though the growth rate of area was negative and nonsignificant. Pigeonpea has shown a significant positive growth rate in area, production and productivity i.e., 2.28 per cent, 6.62 per cent and 3.63 per cent, respectively. Horse gram, black gram and green gram were found to be non-significant.

During the study period, area of finger millet crop showed negative growth due to low output price in the market (Rajpurohit, 1983). Maize has shown positive significant growth in both area and production. The rapid expansion in area under this crop was mainly due to its important features like short duration, adaption to a wide range of soils and climatic conditions and high yield per ha as compared to other cereal crops and also this crop dependent on poultry industry which is on increasing trend. This study is supported by Sathyendra et al., (2016) who found that in Karnataka, maize production was increasing at 10.23 per cent per annum during the study period. Though field bean has less area contribution it had showed positive growth in production and productivity, this might be due to inducement by better relative prices for the crop, relatively low water requirement, availability of good quality seeds and availability of package of practices (Nethravathi and Yeledhalli, 2016). Area, production and productivity of chickpea and pigeonpea had shown significant positive growth. This result was supported with the findings of Saraswathi et al., (2012) reported a positive growth rates in area, production and productivity under chickpea and pigeonpea in Karnataka.

Table.1 Compound annual growth rate in area, production and productivity of different food grains in Karnataka state

\begin{tabular}{|l|c|c|c|}
\hline Crops & Area & Production & Productivity \\
\hline Paddy & $0.29^{\mathrm{NS}}$ & $0.97^{\mathrm{NS}}$ & $0.67^{\mathrm{NS}}$ \\
\hline Sorghum & $-0.89^{\mathrm{NS}}$ & $-0.51^{\mathrm{NS}}$ & $0.38^{\mathrm{NS}}$ \\
\hline Pearl millet & $-1.31^{\mathrm{NS}}$ & $1.32^{\mathrm{NS}}$ & $2.66^{* *}$ \\
\hline Maize & $7.74^{* *}$ & $7.64^{* *}$ & $-0.10^{* *}$ \\
\hline Finger millet & $-1.81^{* *}$ & $-1.09^{\mathrm{NS}}$ & $0.73^{\mathrm{NS}}$ \\
\hline Wheat & $0.36^{\mathrm{NS}}$ & $2.42^{* *}$ & $2.04^{* *}$ \\
\hline Horse gram & $-3.22^{\mathrm{NS}}$ & $-2.81^{\mathrm{NS}}$ & $0.42^{\mathrm{NS}}$ \\
\hline Black gram & $-0.70^{\mathrm{NS}}$ & $-1.05^{\mathrm{NS}}$ & $-0.34^{\mathrm{NS}}$ \\
\hline Green gram & $0.88^{\mathrm{NS}}$ & $-0.61^{\mathrm{NS}}$ & $-1.48^{\mathrm{NS}}$ \\
\hline Field bean & $-0.94^{\mathrm{NS}}$ & $7.28^{* *}$ & $8.30^{* *}$ \\
\hline Chickpea & $6.68^{* *}$ & $8.96^{* *}$ & $2.14^{* *}$ \\
\hline Pigeonpea & $2.88^{* *}$ & $6.62^{* *}$ & $3.63^{* *}$ \\
\hline
\end{tabular}

Note: ** significant at $1 \%$

NS- Non significant 
Policies need to be focused to increase the yields of food grains. Scientific methods of cultivation of different crops and sustainable agriculture need to be carried out to increase the productivity. Research institutes need to be established in the state. The latter factors are important in making agriculture profitable through efficient marketing, access to and adoption of new technologies and providing incentives for making on-farm investment. There is a need to take up productivity enhancing measures in these food grains like varietal improvement, improved cultural practices, distribution of planting materials, disease control measures, and selection of appropriate crop according to agro-climatic conditions and irrigation facilities.

\section{References}

Nethravathi, A.P. and Yeledhalli, R.A. 2016, Growth and instability in area, production and productivity of different crops in Bengaluru division. Int. J. Agric. Environ. Biotechnol., 9(4): 599. 611.

Rajpurohit, A., 1983, Recent trends in agricultural growth rates in Karnataka. Indian J. Agric. Econ., 38(2): 585-590.

Ramachandra, V.A., Basana, R.T., Salunke, R. and Ravusaheb, M., 2013, Growth in area, production and productivity of major crops in Karnataka. Int. Res. J. Agric. Econo. Stat., 4(2): 117-123.

Sarawathi, P.A., Basavaraja, H., Kunnal, L.B., Mahajanshetti, S.B. and Bhat, A.R.S., 2012, Growth in area production and productivity of major crops in Karnataka. Karnataka J. Agric. Sci., 25(4): 431-436.

Sathyendra, A.D. and Devaraj, M., 2016, Production performance of selected agricultural commodities in Karnataka. Int. J. Agric. Sci. Vet. Med., 4(2): 14-20.

\section{How to cite this article:}

Pavithra, N.L., K.V. Ashalatha, J. Megha, G.R. Manjunath and Siddu Hanabar. 2018. Growth in Area, Production and Productivity of Food Grains in Karnataka State, India. Int.J.Curr.Microbiol.App.Sci. 7(08): 2532-2535. doi: https://doi.org/10.20546/ijcmas.2018.708.258 